Saunders MNK and Thornhill A (2006) Forced Employment Contract Change and the Psychological Contract Employee Relations 28.5, 449-467

\title{
Forced Employment Contract Change and the Psychological Contract
}

\begin{abstract}
Purpose: To explore the implications for all employees' psychological contracts of a forced change from permanent to temporary employment status for some employees within an organisation.
\end{abstract}

Methodology/Approach: A random sample of 30 employees, stratified by employment status was selected. Each employee undertook a structured card sort of possible emotional responses to change followed by an in-depth interview to explore and explain their categorisation of these responses.

Findings: The nature of psychological contracts and organisational attachments for both permanent employees and forced temporary workers is complex. Permanent employees generally continue to exhibit relational forms of attachment to the organisation. These, they believe, are reciprocated by the organisation. Reactions from forced temporary workers are more varied. After a period of denial, some develop a more calculative approach to their interactions. Others maintain aspects of their previously developed relational attachments. Only some temporary workers appear to recognise that their future direction is no longer a concern of the organisation. 
Research limitations/implications: Although only based upon one organisation, the findings suggest that the process of psychological contract adjustment is likely to emerge through gradual re-interpretation, rather than through re-negotiation.

Practical implications: Management actions need to be recognised as important in re-defining the nature of psychological contracts. The transitional nature of this process may be prolonged where management imposes transactional contracts and where communication and negotiation to create clear expectations is lacking.

Originality/value of paper: The findings provide new insights into the implications of forcing employees from permanent to temporary contracts for their, and remaining permanent employees', psychological contracts.

Keywords: temporary contract, permanent contract, psychological contract, adjustment

Classification: research paper

\section{ACKNOWLEDGEMENT}

We thank the two anonymous reviewers for their constructive comments and suggestions. 


\section{INTRODUCTION}

In many organisations, the drive to achieve high levels of performance, quality and output, often linked with espoused policies about securing employees' commitment to and integration with business goals (e.g. Guest, 1987; Storey, 1992), has been advanced alongside organisational restructuring, downsizing and employment change. Concurrent with these developments, analysts have noted a long term but modest growth in fixed term and temporary employment contracts (Guest, 2004). Estimates regarding the extent of such flexible contracts vary considerably both between sources and between countries. For example, according to Eurostat [1], the proportion of temporary workers as a percentage of total employees in the European Union was 12.5 percent in 2000, ranging from 32 percent in Spain through 6.8 percent in the UK (United Kingdom) and under 3 percent in some accession countries. Such flexible employment practices, it is argued, are part of a longer term trend that commenced in the early 1950s and has continued throughout the 1990s (Millward et al., 2000; Watson, 1994).

The extent to which organisations have altered their employment practices deliberately through increased use of temporary workers, including sub contractors and those on fixed term and temporary contracts, is also open to debate. Research in general has argued that organisations have not set out deliberately to create an employment periphery (e.g. Millward et al., 2000; Penn, 1992; Pollert, 1988). Rather, the use of such flexible employment contracts has been in response to sectoral shifts in the structure of employment and the need to cut costs (Mayne et al., 1996; Mueller, 1992; Pollert, 1988). Whilst it has been suggested that the majority of organisations have reacted to these changes by using flexible contracts opportunistically and, perhaps, reluctantly (Purcell, 2000), it has also been 
suggested that increases in their use are due to more fundamental changes in employers' policies and practices (Casey et al., 1997). In particular, Guest (2004) argues the CRANET surveys confirm that, across Europe, managers believe their adoption of fixed term and temporary contracts and the use of casual workers is increasing. At the same time there are also indications that certain types of worker actively seek such flexible work (Guest, 2004).

The movement to create organisational flexibility and responsiveness has also been associated with downsizing, partly through subcontracting those functions no longer considered core, and partly through delayering and restructuring. Downsizing inevitably forces those who survive to reconsider their employment relationship with an organisation. The impact of downsizing upon the relationship between employees and their employer, and, in particular, on the commitment of those employees who as permanent employees has been well documented (e.g. Brockner and Greenberg, 1990, Kets de Vries and Balazs, 1997). However, the implications for organisations that, as part of an organisational restructuring, make employees redundant and then re-employ them as temporary workers are less well researched. These people are not traditional redundant employees covered by studies such as Turnbull and Wass's (1997) research, nor are they survivors who remain employees. Rather, they are people who still undertake work for the organisation, but for whom there has been a forced change in employment contract. For such people, this process of change in contract appears likely to impact upon their definition of the content of their psychological contracts (Millward and Brewerton, 1999).

In this paper we explore the impact on all employees of introducing temporary contracts as a forced change in employment status for a group of workers within an 
organisation. These workers had previously held permanent contracts but were, through altered labour market conditions, forced to take temporary contracts. While these people were contracted for a specific task for a limited but not fully specified period, their former colleagues maintained their permanent contract status.

Conceptually, this study permits an exploration of relationships between a number of theoretical constructs relating to flexible employment contracts, the psychological contract and organisational justice. By contrasting the reactions of those who were forced to take temporary contracts with those whose contracts remain permanent, we are able to explore the implications of this type of organisational change on the nature of the psychological contracts and commitment for both groups. In terms of practical application the conclusions from this case study point to the need for organisations to be much more mindful about the implications of change for the psychological contract.

\section{THE PSYCHOLOGICAL CONTRACT, FLEXIBLE EMPLOYMENT CONTRACTS AND ORGANISATIONAL JUSTICE}

Rousseau (1995: 9) defines the psychological contract as "individual beliefs, shaped by the organization, regarding terms of an exchange agreement between individuals and their organization." In her subsequent discussion, she highlights that these beliefs can arise from a wide range of factors such as overt promises made between an individual and her or his supervisor, interpretations of patterns of past exchanges and observations of others' experiences. Drawing upon this, Millward and Brewerton (1999) emphasise that psychological contracts can be described in terms of both the nature of the beliefs and the process through which these beliefs arise. 
Within the literature, the nature of employees' beliefs about the exchange agreement has been differentiated in terms of its transactional or relational orientation. A psychological contract with a transactional orientation is argued to focus upon short term, largely financial benefits to the employee (Rousseau, 1995). Perceived terms of employment are predicted to be calculative and instrumental with limited reciprocity, focussing upon beliefs about remuneration (Herriot and Pemberton, 1996). For such contracts, affected employees will concentrate on distributive outcomes, there being limited identification and integration with the organisation (Millward and Brewerton, 1999). Thus, loyalty and commitment are unlikely to be an integral part of the transactional psychological contract.

In contrast a psychological contract with a relational orientation is likely to have evolved over time as a partnership develops between employee and employer (Rousseau, 1995), implying mutuality and reciprocity between them. Perceived terms of employment are therefore likely to be more than remunerative, incorporating beliefs about support from the employer such as training and personal and career development. Processes through which equity and fairness are affirmed are important in maintaining a relational contract, with the nature of beliefs becoming more pronounced as they are assessed over time (Herriot and Pemberton, 1996). Consequently, a relational psychological contract is characterised for the employee as trusting their employer, high affective commitment, high integration and identification with the organisation, contribution and long term commitment (Rousseau, 1995). Drawing upon this, Rousseau (1995) argues that a permanent employee is more likely than a temporary worker to have a relational orientated psychological contract. Conversely, a temporary worker is more likely than a permanent employee to have a transactional orientated psychological contract with an employer. 
In his 2004 review article, Guest argues that the psychological contract is at the heart of issues related to flexible employment contracts, with consequences for employees' attitudes and behaviours. He suggests that an individual's disposition to their psychological contract will be affected directly by contract related, organisational, occupational and wider contextual factors. Guest emphasises that whether the person is employed in a contract of choice (permanent or temporary) has been shown consistently to be an important influence.

Studies regarding the relationship between type of contract and the nature of attachments to an organisation suggest, albeit with limited evidence, that those on temporary employment contracts show either the same or lower commitment to the organisation than those on permanent contracts (Guest, 2004). Permanent employees forced to become temporary workers would appear likely to have a low preference for such temporary work. This would probably be expected to result in the adoption of a more instrumental approach, as their psychological contracts are re-interpreted as transactional, reducing whatever level of their sense of affective commitment to the organisation they felt. Similar reactions may also occur where an organisation requires those who remain as permanent employees to engage in greater functional flexibility, through job enlargement. Adapting lles et al. (1990), temporary workers may be more committed to the value of paid employment, their career and perhaps their profession where appropriate rather than to their specific job or their employing organisation. Consequently transactional psychological contracts seem less likely to generate a sense of organisational identity (Millward and Brewerton, 1999) and organisational commitment (Herriot and Pemberton, 1997). 
In some cases, a move to temporary work may also be seen as preferable by individuals (Marler et al., 2002). Handy (1989) is enthusiastic about a future in which increasing numbers of employees are peripheral to organisations, choosing to have a portfolio of careers, resulting in benefits such as a better work-life balance, greater control and variety. Others have subsequently predicted the decline of traditional careers within organisations emphasising benefits to be realised (e.g. Bridges, 1995; Golzen and Garner, 1990). Within this, Cohen and Mallon (1999) point to the complexity of feelings towards, and reactions resulting from, becoming a temporary worker. The attractions associated with obtaining greater freedom have also been associated with greater insecurity, potentially lower control over hours of work and working patterns, and a continuing need to find new work. Any sense of greater independence and control might potentially be undermined by a growing dependence on a small number of clients to supply work, often including the previous employing organisation. These ideas of preference for temporary work have been linked to workers' skill and knowledge levels to produce a typology of temporary contracts (Marler et al., 2002):

- boundaryless worker: high preference for temporary work and a high skills/knowledge level;

- $\quad$ permanent temporary worker: high preference for temporary work and a low skills/knowledge level;

- transitional worker: low preference for temporary work and a high skills/knowledge level;

- traditional worker: low preference for temporary work and a low skills/knowledge level. 
This typology emphasises that, for some, temporary work is the contract of choice. It also implies that personal preferences for temporary work are likely to influence feelings towards different types of psychological contracts. In particular high preferences for temporary work would seem likely to accentuate positive feelings towards transactional orientated psychological contracts, whereas low preferences for temporary work would accentuate negative feelings towards transactional orientated psychological contracts. However, as highlighted by Guest (2004), we need to learn more about such workers and the affect of high and low preferences on their psychological contracts.

Organisational justice theory (Greenberg, 1987) focuses on perceptions of fairness in organisations, by categorising individuals' views and feelings about their and others' treatment within an organisation. As such it has close parallels with the concept of expectations based upon beliefs and the processes through which these beliefs arose in the definition of the psychological contract outlined earlier (Pate et al., 2003, Tekleab et al., 2005). Perceptions about outcomes of decisions taken, form the basis of distributive justice (Homans, 1961; Leventhal, 1976). Perceptions about the processes used to arrive at, and to implement, these decisions form the basis of two further dimensions of justice that are sometimes treated as one in the literature: procedural justice and interactional justice (e.g. Cropanzano and Greenberg, 1997). Procedural justice focuses on perceptions of fairness of procedures used to make decisions (Thibaut and Walker, 1975). This has been distinguished from interactional justice which focuses on perceptions about fairness of interpersonal treatment received during implementation (Bies and Moag, 1986). However, there has been considerable debate concerning interactional justice. Initially researchers (e.g. Bies and Moag, 1986; Greenberg, 1993) suggested that it consisted of two distinct types of interpersonal treatment; treatment of people 
(interpersonal justice) and explanations provided to people (informational justice). Subsequently, it was argued that, as interactional justice produces the same type of perceptual outcomes as procedural justice, it should be considered a facet of procedural justice rather than as a separate dimension (e.g. Cropanzano and Greenberg, 1997). More recently, research has suggested that procedural, informational and interpersonal forms of justice are three empirically distinct dimensions (Colquitt, 2001; Kernan and Hanges, 2002).

Consideration of perceived fairness using these dimensions of organisational justice raises the possibility of breaches of the psychological contract. An individual's psychological contract is breached when perceived unmet obligations of the organisation are identified (Morrison and Robinson, 1997). In many instances a minor breach may be overlooked if the quality of the organisation's support and relationships with employees are perceived to be high (Tekleab et al., 2005), thereby maintaining the psychological contract. Where it is believed that the organisation has not maintained the psychological contract adequately, acting unfairly or breaking a promise, the resulting affective and emotional state is termed violation (Morrison and Robinson, 1997). Such emotions are likely to be wide ranging including disappointment and frustration as well as more extreme responses such as anger and resentment (Pate et al., 2003).

This variety of emotional responses also allow for the possibility of differential impacts on relational and transactional psychological contracts. Employees, who prior to downsizing were employed on permanent contracts, appear more likely to view and have their psychological contract viewed by that organisation as relational. Following downsizing where these individuals remain on permanent contracts, their psychological contract may be breached for reasons such as perceived unfair 
treatment of themselves or others and, where violated, is likely go through a period of re-negotiation (Herriot and Pemberton, 1996). The outcome of this could be either continuation of a relational or movement towards a more transactional orientated psychological contract. Such employees are likely to appraise the fairness of the decision making processes and the appropriateness of the outcomes against referent standards (procedural and distributive justice, Pate et al., 2003; Tekleab et al., 2005) within the context of their own preferences for temporary work. The sensitivity with which these decisions are implemented, and the manner in which they are communicated, is likely to contribute to this assessment (interactional justice, Kickul et al., 2002). Where movement towards a transactional orientated psychological contract occurs, the importance of informational and interpersonal justice appears likely to decline as explanations, relationships, and social accountability become less important. Workers who are employed on temporary contracts prior to downsizing and subsequently remain on such contracts are likely to continue to view their psychological contract as having a transactional orientation. These workers are likely to focus upon the outcomes of the exchange implied by their contracts and, to a lesser extent, the processes by which these were achieved, characterised by the distributive and procedural dimensions of organisational justice already identified and within a framework of their own preferences for temporary work.

The psychological contracts of workers who prior to downsizing were employed on permanent contracts but post downsizing become temporary are likely to have been breached and, where violated, re-interpreted. The organisation's treatment of these individuals is now likely to reflect a transactional orientation to the psychological contract, focusing upon distributive dimensions. However, the extent to which a change of employment contract results in an employer's obligations being perceived 
as unmet by the individual whose contract has been changed is unclear. New temporary workers may still be basing their psychological contracts at least partially on treatment prior to downsizing and considering all dimensions of justice. Thus, there may be marked differences in the importance now given to procedural and interactional (interpersonal and informational) justice. Conversely, individuals moving from being temporary workers prior to downsizing to permanent employees post downsizing are likely to be few in number. However, in such instances it seems probable that they will be moving from a transactional towards a relational orientation to their psychological contracts.

Against this background, we now turn to the case study organisation to examine the implications of some employees being forced to change from permanent to temporary contracts for all employees' psychological contracts. This assessment is made within the context of permanent employees' and temporary workers' preferences for permanent employment or temporary work.

\section{A CASE OF MISMATCHED CONTRACTUAL EXPECTATIONS? THE NEW TEMPORARY WORKERS}

The case study company, referred to as Flexco, commenced existence as part of a larger organisation. The larger organisation had developed an integrated and strategically oriented Human Resources function. Systems had been established to support training and development of employees, and there was a strong internal labour market. Employees were effectively shielded from the external world and exchanged their commitment for job security and steady career development. Those employed within what was to become Flexco provided a variety of training and management development courses to other parts of the organisation and were 
employed on permanent, predominantly full-time, contracts. As part of this, time was made available for their own skills updating and training provided.

Transformation of Flexco to independent operating status resulted in further change. Over a year it was restructured and finally, through a management buyout, became a separate company. This had two major consequences. Firstly, Flexco's business was now the management, sale and administration of the training and management development services they offered to clients; the actual delivery of courses being seen as less important and the number of permanent employees being reduced through downsizing. Secondly, all those delivering Flexco's courses were relabelled consultants and informed that they would now only be employed as and when needed, being forced to become knowledge and skill based temporary workers. These changes were accompanied by a flatter, non-bureaucratic structure with a head office and regional satellites. Those employees who maintained their permanent contract status continued to undertake similar functional roles as prior to Flexco becoming a separate company. However, whilst continuing to focus on sales, administration or the management of one of the satellite offices, these employees were now also required to be more functionally flexible. Those workers now on temporary contracts (consultants) were no longer shielded from the external world, their contract guaranteeing them payment for delivering courses for a fixed number of days during the first year of Flexco's operation. This equated to an average of approximately two days work per week. Subsequent to this, no commitments were given regarding the amount of work that would be available. Rather consultants would be contracted for specific training tasks on an 'as needed' basis. It was made explicit in their contracts that, whilst in the past Flexco had provided training opportunities, as temporary workers they would need to make provision for their own training and development. This had considerable 
implications for these workers' everyday working experiences. They had been forced to accept short term transactional contracts and adopt a portfolio approach to their work, seeking contracts with a number of other organisations.

Flexco's senior management agreed it would be appropriate to discover both the remaining permanent employees' and newly created temporary workers' reactions to the downsizing. From these data, it is possible to explore the implications of forcing permanent employees to become temporary workers in relation to their and the remaining permanent employees' contract preferences and their attitudes to the organisation. In particular, their beliefs about their psychological contracts, the extent to which these had been breached or violated and the implications of this for the nature of their attachments to the organisation can be examined.

\section{METHOD}

Data were collected three months after downsizing and restructuring through two interrelated methods that utilised a structured and an unstructured approach consisting of a card sort and in-depth interviews that built on this card sort. Card sort and in-depth interview data were obtained from 50 percent of both Flexco's permanent employees, including the organisation's director, and their temporary workers. This sample was stratified to represent the permanent employees, namely management, sales and administration, and the temporary workers ('consultants'), as well as employees based at both head office and regional satellites.

The card sort followed the procedure outlined by Saunders and Thornhill (2004) in which participants were asked to sort forty cards each containing a single emotion that might be experienced in relation to organisational change. These emotions 
reflected a wide range of possible feelings (Table II) and were derived from the literatures relating to psychology and stress (Brockner, 1990; Brockner and Greenberg, 1990; Brockner et al., 1987; Brockner et al., 1992; Lazarus and Folkman, 1984). Sorting emotions was chosen as the initial means to collect data because it was felt that this approach would draw directly on the experiences of each participant, providing not only a sense of validity but also a subsequent means to explore these through the in-depth interview. Each participant was informed that the purpose of the study was to establish and understand her or his feelings 'in relation to the recent changes at [Flexco]', and it was stressed that there were no wrong answers. After assurances of confidentiality and anonymity had been offered and consent obtained, participants were asked initially to categorise each card into either 'do not feel' or 'feel to some extent'. Those cards that contained an emotion categorised as 'do not feel' were removed and recorded, following this initial sort. Each participant was then asked to undertake a second sort of those cards containing an emotion that he or she felt to some extent. During this second sort, participants were asked to select those cards containing an emotion that she or he 'felt strongly'. From these they were asked to identify three about which they 'felt most strongly'. This provided an initial means of organising and analysing these data related to whether each emotion had 'not been felt', 'felt to some extent', 'felt strongly' or 'felt most strongly'. It also allowed the subsequent interview to be grounded in each participant's categorisation of the emotions that he or she had experienced because of organisational change, enabling participant validation during the interview (Pidgeon, 1996).

The card sort was followed immediately by an interview structured around each participant's categorisation of these emotions, of approximately one hour's duration. This sought to explore and explain each level of this categorisation commencing 
with the emotions that were felt most strongly. As part of this process, participants were encouraged to discuss their emotions in the contexts of before and after the downsizing and their preferences for temporary and permanent contracts. These associated discussions also allowed individuals' perceptions of their psychological contracts to be established.

Within each interview discussion of an individual's preference for a temporary or permanent contract and their perceived psychological contract was introduced by using a question of the format: "... I've noticed that you mentioned your relationship with [Flexco] when you were talking about feeling.......can we talk about this further?" During subsequent discussion non leading prompts such as "that is interesting, can you tell me more" and "can you explain a bit more why you feel like this" were used. Through this process of prompting each participant identified their employment contract preference and the components and terms of the exchange agreement between themselves and Flexco.

Subsequently these card sort and in-depth interview data were analysed to explore and make sense of relationships between individuals' actual contracts with Flexco, their preferences for permanent and temporary work, their beliefs about their psychological contract and their feelings in relation to the changes. After agreeing initial definitions, we undertook this analysis independently before comparing our categorisations. Where we disagreed regarding categories, we debated and clarified the definition, subsequently agreeing the categorisation. By adopting check coding (Miles and Huberman, 1994) problems of reliability associated with a single person coding were minimised. 
Initially each paragraph of interview data was categorised according to whether the participant preferred permanent work, temporary work, had mixed views or the paragraph was outside this categorisation. Preference for permanent employment was indicated by combinations of comments relating to a desire to continue working for one organisation and for security such as "I'm hopeful my job will last" (administrator) and "I don't like financial insecurity......there is a feeling of isolation, of insularity, of having to work much more by oneself" (consultant). Preference for temporary work was indicated by comments such as "I'm comfortable with self employment... I am positive there are more opportunities." (consultant) and "I've been there and know what it's like and I'm optimistic." (consultant); Interview notes such as 'respondent appeared pleased with contract' were used to triangulate categorisations.

This process was repeated to categorise each paragraph according to whether a respondent discussed an aspect or aspects of an exchange agreement between themselves and Flexco in relational or transactional terms or whether there was uncertainty, suggesting the psychological contract was undergoing re-evaluation. Comments such as "I'm in control and I'm believed in. I get lots of support" (regional manager) and "They [management] make me feel part of the organisation... I want us to succeed." (consultant) implied the mutuality and reciprocity of a relational psychological contract. In contrast phrases such as "I've not been involved..." (administrator), "[manager's name] used to ask how things are going, he's now more of a controller" (consultant) and "[Flexco] say we can't have meetings 'cause they're too expensive to hold" (consultant) implied a more transactional contract in which identification and integration with Flexco was limited. This categorisation, used in conjunction with the card sort data, allowed individuals' beliefs about their psychological contracts with Flexco to be explored within the contexts of their actual 
contracts and preferences for permanent or temporary work, emotions felt and their reasons for these. In doing this we sought to develop our analysis in a way that was grounded in our respondents' data and which would be recognised as valid by them.

Following work by Pate et al. (2003) and others, organisational justice theory was introduced as a perspective from which to view these data (Giles, 2002); in particular to explore and make sense of individuals' beliefs about their psychological contracts and how these had been influenced by their experiences of the organisational change process. This analysis focused on responses from those working for Flexco in either permanent or temporary contracts and their relationships with the organisation. Each sentence within these responses was coded regarding the presence or absence of distributive, procedural, informational and interpersonal justice. As previously a process of check coding was adopted, initial coding being undertaken independently using agreed definitions derived from the literature prior to considering those sentences where we disagreed regarding the category assigned.

Card sort and interview data therefore enabled individuals' preferences for temporary and permanent contracts and their perceptions of their psychological contracts to be established and compared with the organisational reality stated by the organisation's director. It is to these preferences and perceptions that we now turn, commencing with an overview of the director's views of those on permanent and those on temporary contracts. Employees on permanent contracts are then considered in terms of their contract preference (all preferred permanent) and their perceptions of their psychological contracts. Subsequently we consider those workers on temporary contracts, using Marler et al.'s (2002) typology to group them 
by temporary contract preference when exploring their perceptions of their psychological contracts.

\section{CONTRACT PREFERENCES AND VIEWS OF THE PSYCHOLOGICAL CONTRACT}

\section{Flexco's Director's view of individuals' contracts}

At the time of data collection Flexco's managerial, administrative and sales personnel were employed on permanent contracts, whilst consultants were on temporary contracts. An interview with the Flexco Director emphasised that, from his perspective, only consultants had transactional contracts with Flexco. In discussing his enthusiasm for Flexco he referred to his "strong team" and how he believed these permanent employees all would "go the extra mile" for Flexco. He did not feel that they lacked commitment, citing the strong sales performance as evidence. In contrast, when discussing the emotion 'determined' he referred to his determination "to make the business work" highlighting the importance to this of the organisation's transactional relationship with consultants. In this discussion he emphasised that consultants were only paid for "contract time" and that the "core focus" of the business was "sales" and the "performance of sales teams" rather than “consultants' loyalty or service delivery." When asked about employees' (including consultants') attitudes to the changes at Flexco, he emphasised that all employees were "not resistant but [were] in general supportive of the changes". This is in contrast to the responses of five of the twenty permanent employees and seven of the ten temporary workers interviewed who felt negative about the changes. 


\section{Permanent employees' contract preferences and views of their psychological contracts}

The largest category of respondents, those employed by Flexco on permanent contracts consisted of 20 respondents, all of who preferred permanent contracts (Table I). Of these, 15 (50 percent of all interviewees) believed the focus of their psychological contract with Flexco was relational. With few exceptions, these 15 employees justified the wide range of emotions they selected as positive feelings in relation to the recent changes at Flexco (Table II). In discussing these choices they emphasised they were 'determined' to "make [Flexco] a success and to shoot the competition out of the water" (regional manager), and were 'confident', 'enthusiastic' and 'optimistic' for Flexco's future. Their sentiments were typified by a sales representative who, in explaining his enthusiasm said: "there are a lot of people's lives tied up with the management buyout. We're all in this together. People have confidence in me and I will prove them right. There is a good team spirit and I believe in myself, the products and the organisation" and by a head office manager who argued that Flexco had a "secure future" and "the company can go forward". Such sentiments highlight feelings of mutual trust and reciprocated confidence between employees and senior managers and the perception of a shared common goal. Another manager summed up the feelings of many of these employees likening the creation of Flexco to "Noah's Ark". Mutuality, loyalty and identification were also emphasised by comments such as "we're all in this together", indications of trust being provided by comments such as “with [management team's names] in the driving seat, we've got an experienced team."

[take in Table I and Table II] 
In contrast, two respondents employed on permanent contracts perceived their psychological contract with Flexco was, subsequent to the changes, transactional (7 percent) (Table I). Although there was overlap in the emotions they selected and those selected by respondents who perceived they had a relational contract, their subsequent justifications highlighted these feelings in relation to the changes were predominantly negative providing insights into the violations that had caused this change. One, an administrator, felt that the sense of fairness and mutuality that previously existed in her relationship with management had gone and felt unclear about her future role within Flexco. She justified her selection of the emotions 'demoralised' and 'indifferent' (Table II) in relation to limited communication, stating she now "felt isolated from the rest of [Flexco]..." and "...did not feel part of its developments". In contrast the other, a sales representative, was 'positive', 'cheerful' and 'enthusiastic' arguing that she was "not reliant on the company" and that if she did not get the financial rewards she wanted from Flexco, she could easily move to work for a competitor. This also emphasised her low preference for temporary work.

Three (10 percent) permanent employees appeared to be re-evaluating their psychological contract with Flexco (Table I). This group of employees had mixed emotions, ranging from being 'confused' and 'concerned' to 'enthusiastic' and 'optimistic' (Table II), that from discussion appeared to be related to their personal situation with Flexco. The stage of these evaluations varied, although the focus appeared to be breaches to their psychological contract caused by wider changes to Flexco, in particular the moving of consultants to temporary contracts. One regional manager outlined this breach: "Because of the changes I'm less enthusiastic than I used to be. The changes haven't affected me personally.... maybe within the next few years I will need to change to being self employed. If I 
was pressurised to change status, I would resist. It is a no win situation and I would be worse off." Another commented: "I'm still enthusiastic about the job, but not the changes at [Flexco]. I've started looking. We don't practice what we sell. I'm waiting for the axe man. I resent the way I feel now. I've been led up the garden path." These employees appeared to be revaluating their own loyalty to Flexco and, in the case of the latter, were close to concluding that their psychological contract had been violated. They feared that their working hours would be cut, suggesting a transactional re-orientation of their psychological contracts and recognition that in the future, despite preferences, they might not have permanent work.

\section{Temporary workers' contract preferences and views of their psychological contracts}

Psychological contract perceptions of those who had temporary contracts with Flexco were more varied. Using Marler et al.'s (2002) categories these skilled temporary workers can be divided into the six (20 percent of all respondents) who had a low preference for temporary work (transitional workers) and the three (10 percent) who had a high preference temporary work (boundaryless workers). In addition there was one who appeared to have mixed views (Table I). The perceptions of the psychological contract for each of these categories of temporary workers will now be considered in turn.

Analysis of interview data revealed that three of the six transitional workers still believed the focus of their psychological contract was relational. Although these workers felt 'vulnerable' and 'worried' because they were "not sure what the future holds" in general they felt positive about the changes (Table II). Despite now being on temporary contracts (which were not their contracts of choice), they still felt a 
mutual bond between the organisation and themselves. One consultant stated typically , "my loyalty for Flexco had developed [over 4 years]... Flexco had become used to using us. I'm not sure if it [changing the contract] is any easier for them". However, like others she perceived that her psychological contract with Flexco, whilst still relational was changing. As part of this she commented about a lack of communication and no real negotiation: "no one is talking to me and asking me what I want any more", emphasising her perception about changes in procedural treatment and a reduction in interpersonal justice and suggesting a possible breach.

The remaining three transitional workers outlined their feelings about the change less positively, emphasising that they felt 'powerless', 'insecure' and 'vulnerable' (Table II) and that being temporary was not their contract of choice. One was reevaluating his psychological contract, whilst two now believed their contract with Flexco was now transactional. Such feelings were typified by the statement "I'm determined from my own perspective to come through whatever happens. I have a responsibility to work for [Flexco], but no loyalty." These workers perceived that their interactions with Flexco were no longer based on a personal relationship with little communication, a typical comment being: "I think I do a good job, but as far as they [management] are concerned, I might as well not exist". This indicates a reduced emphasis on the interpersonal and informational aspects of organisational treatment and implies that these temporary workers felt these aspects of their previous relational contracts had been violated.

Following the downsizing, like the other temporary workers, transitional workers were only paid for time spent delivering courses. Whereas work time had previously been available to meet with others, discuss ideas and offer feedback this was no longer the case. In addition, training to develop and share new skills was no 
longer provided, prompting comments such as "my career, who cares?" This indicates that these transitional workers had recognised the move by Flexco to transactional contracts. They felt that new consultants would be used to keep costs down, indicating further perceptions about unjust treatment in terms of outcomes. One transitional worker summarised this as "we'll use the cheapest", emphasising his perceptions about the transactional orientation of the psychological contract.

Boundaryless workers either viewed their psychological contract as transactional or were in the process of re-evaluating it. In all instances, these workers selected predominantly positive emotions (Table II) and talked about the changes in positive terms. Having embraced temporary work in the past they were cheerful, positive and comfortable about the changes. Their positive feelings about temporary contracts and acceptance of transactional psychological contracts were typified by one who stated: "I'm calm because I'm used to freelance. I had worked for myself for over 15 years. I've had lots of ups and downs before. My home life and financial life is stable. It's not my only source of income or company l'm involved with... I've been there and know what it's like." The one worker with mixed preferences about temporary contracts (Table II) also perceived his relationship with Flexco as transactional emphasising a lack of loyalty and focus upon himself: "I have a responsibility to work for [Flexco], but no loyalty... It is time to say 'what about me' and start looking for another job."

\section{DISCUSSION}

The review of literature relating to the psychological contract and to organisational justice suggests that there are likely to be significant implications for organisations using flexibility strategies to manage the contribution of their human resources. 
This paper has explored these implications in relation to both those employees who remained on permanent contracts and those who, as part of an organisational restructuring, are made redundant and then re-employed on temporary contracts; the latter being a group who have not been widely-researched. While this paper focuses on one such organisation, this phenomenon is apparent across different industrial sectors.

Downsizing has been shown to impact on those who have been categorised as its survivors, even where their contracts ostensibly remain largely unaffected (e.g. Brockner, 2002; Brockner and Greenberg, 1990; Doherty et al., 1993). Thus, even for those who remain on permanent contracts, the resulting changes to the structures, culture and level of employment in an organisation may create altered perceptions about the employment relationship and a recognition that the exchange of "loyalty for security" (Hendry and Jenkins, 1997: 39) has been superseded. The relational/transactional orientation has been used to suggest how both permanent employees and temporary workers affected by downsizing and restructuring may react to these changes through re-interpretation of their psychological contracts.

In the present context the relational/transactional orientation has been applied to those who not only remained core to the organisation, as permanent employees, but also to those placed on its periphery, as temporary workers. It was expected that permanent employees would be more likely to have relational psychological contracts and temporary workers transactional contracts. We also suggested that individuals' preferences for permanent or temporary work would act as a moderating variable in relation to their type of psychological contract. Organisational treatment was also thought to have an impact on the nature of 
individuals' psychological contracts, with this variable being assessed through perceptions about the different dimensions of organisational justice.

From the case study, we found that employees who remained permanent were more likely to view their psychological contracts as relational, whilst those forced to become temporary workers were more likely to view their psychological contracts as transactional. However, within each group there were differences. Some employees who remained permanent, but who felt negative about the changes, explained these feelings of violation of their psychological contract in terms of their own interpersonal treatment, emphasising their perceptions of its increasingly transactional focus. In some instances these employees, all with a low preference for temporary work, expressed a concern that if they remained with the organisation they would face a change to a temporary contract in the future. This appeared to be based upon observations of the outcomes for others who were now on temporary contracts. Conversely, although the contract with temporary workers was defined by the Director as transactional, a substantial proportion of these workers, who also had a low preference for temporary contracts, still felt that the focus of their psychological contracts were relational. These workers appeared positive in relation to the changes, although there were indications of possible breaches in the psychological contract, in particular with regard to their interpersonal treatment. For these workers, further breaches would seem likely to result in their psychological contracts being re-evaluated. In contrast temporary workers who had a low preference for such contracts and had already concluded their psychological contracts were now transactional appeared to feel negative in relation to the changes. These temporary workers felt that their psychological contracts had been violated, and that the interpersonal and communication aspects of their previous relationship with Flexco were no longer important to the 
organisation. Temporary workers with a high preference for such contracts also appeared to recognise the transactional orientation of their psychological contract but were, in general, positive about the changes to the organisation.

These findings suggest that for significant numbers of individuals in this situation, the relationship between the nature of their employment contract and their psychological contracts will be more complex than initially suggested. Where an individual is employed in their contract of choice, be it permanent or temporary, satisfaction of their personal preference acts as a positive context within which their perceptions of the psychological contract are developed. In particular the level of interpersonal treatment and the provision of information will be perceived more positively, where the individual is employed in their contract of choice.

As implied by our previous discussion, organisational justice theory allowed exploration of the linkages between organisational change and the psychological contracts of both permanent employees or temporary workers. Literature suggests that all forms of organisational justice - distributive, procedural, informational and interpersonal - are likely to continue to be important for permanent employees where they view their psychological contracts in relational terms (Pate et al., 2003, Tekleab et al., 2005, Kikul et al., 2002). Conversely, those forced into temporary work might be expected to be more concerned with the outcomes expected from an exchange (Marler et al., 2002), as implied by a transactional psychological contract. They are likely to be less concerned with procedural and informational justice, as involvement, explanations and social accountability are of less importance in temporary work situations. 
From our case study findings, we found that for those forced from permanent to temporary status, a significant divergence occurred in the interpretation of their psychological contracts. The organisation appears to have interpreted the psychological contracts of those affected as being largely transactional, focusing on the nature of exchange and outcomes. However, for many of these temporary workers, particularly those with a low preference for temporary work, there was evidence that they appeared to be continuing to interpret their emerging psychological contracts according to the relational dimensions that characterised their preceding contract, especially in relation to interactional forms of justice. Where temporary workers perceived that their interpersonal treatment was fair and that fair explanations were provided by the organisation, they were more likely to continue to perceive their contract as relational. In contrast, where such treatment was no longer considered fair this appeared to indicate a breach in their psychological contract or, in the case of those who now considered their contracts transactional, a violation. This resulted in a more instrumental view of their relationship with the organisation.

The case study demonstrates that for forced temporary workers moving from a relational to a transactional contract is likely to be a staged process, as they gradually adjust to and accept the new organisational reality and that of their own positions within it. Rather than any deliberate sense of engagement through renegotiation (Herriot and Pemberton, 1996) this psychological contract adjustment appears likely to occur emergently, through a process of gradual re-interpretation brought about through perceived breaches resulting in violation. Management actions are important in helping to re-define the nature of psychological contracts, towards a transactional state, for those forced onto temporary contracts. In the case study context, management did not recognise temporary workers' contract 
preferences or that they might continue to feel some sense of relational attachment to the organisation. By imposing its transactional nature with limited communication, they were more likely to ensure the loss of the vestiges of this attachment through perceived violations. The transitional nature of this adjustment process may also be prolonged by a lack of communication and any negotiation to create new, clear expectations for those affected by these changes. This is also likely to have implications for how those on permanent contracts perceive their own psychological contracts where they observe what they consider to be unfair treatment of others with no explanation. Thus, the importance of establishing procedural justice and maintaining a sense of both interpersonal and informational justice for those undergoing or observing such a transition is supported. Simply allowing the changed basis of the new psychological contract to become apparent to those affected, particularly in relation to those who find themselves forced into temporary work, may lead to stronger adverse reactions (Brockner, 1990) from both temporary workers and permanent employees and produce a more calculative approach in the longer term.

\section{REFERENCES}

Bies, R.J. and Moag, J.S. (1986), "Interactional Justice: Communication Criteria for Fairness", in Lewicki, R., Sheppard, B. and Bazerman, M. (Eds.) Research on Negotiation in Organizations, JAI Press, Greenwich, CT, pp. 43-55.

Bridges, W. (1995), Job Shift, How to Prosper in a Workplace without Jobs, Nicholas Brearley, London. 
Brockner, J. (1990), "Scope of justice in the workplace: how survivors' react to coworker layoffs", Journal of Social Issues, Vol. 46, No. 1, pp. 95-106.

Brockner, J. (2002), "Making sense of procedural fairness: how high procedural fairness can reduce or heighten the influence of outcome favorability", Academy of Management Review, Vol. 27, No. 1, pp. 58-76.

Brockner, J., Grover, S., Reed, T., Dewitt, R. and O'Malley, M. (1987), “Survivors' reactions to layoffs: We get by with a little help from our friends", Administrative Science Quarterly, Vol. 32, No. 2, pp. 526-541.

Brockner, J. and Greenberg, J. (1990), "The impact of layoffs on survivors: An organizational justice perspective", in Carroll, J.S. (Ed.), Applied Social Psychology and Organisational Settings, Lawrence Erlbaum Association, Hillsdale, NJ.

Brockner, J., Tyler, T.R. and Cooper-Schneider, R. (1992), "The Influence of Prior Commitment to an Institution on Reactions to Perceived Unfairness: The Higher They Are, the Harder They Fall”, Administrative Science Quarterly, Vol. 37, No. 2, pp. 241-61.

Casey, B., Metcalf, H. and Millward, N. (1997), Employers' Use of Flexible Labour, Policy Studies Institute, London.

Cohen, L. and Mallon, M. (1999), "The transition from organisational employment to portfolio working: perceptions of 'boundarylessness", Work, Employment and Society, Vol. 13, No. 3, pp. 329-352. 
Colquitt, J.A. (2001), "On the Dimensionality of Organizational Justice: A Construct Validation of a Measure" Journal of Applied Psychology, Vol. 86, No. 3, pp. 386400.

Cropanzano, R. and Greenberg, J. (1997), "Progress in organizational justice: tunnelling through the maze", in Cooper, C.L. and Robertson, I.T. (Eds.) International Review of Industrial and Organizational Psychology, Volume 12, Wiley, Chichester, reprinted in Cooper, C.L. and Robertson, I.T., (Eds.), (2001), Organizational Psychology and Development, Wiley, Chichester, pp. 243-98.

Doherty, N, Tyson, S. and Viney, C. (1993), "A positive policy? Corporate perspectives on redundancy and outplacement", Personnel Review, Vol. 22, No. 7, pp. 45-53.

Giles, D.C. (2002), Advanced Research Methods in Psychology, Routledge, Hove.

Golzen, G. and Garner, G. (1990), Smart Moves, Blackwell, Oxford.

Greenberg, J. (1987), “ A Taxonomy of Organizational Justice Theories” , Academy of Management Review, Vol. 12, No. 1, pp. 9-22.

Greenberg, J. (1993), "The Social Side of Fairness: Interpersonal and Informational Classes of Organizational Justice", in Cropanzano, R. (Ed.), Justice in the Workplace: Approaching Fairness in Human Resource Management, , Lawrence Erlbaum Association, Hillsdale, NJ, pp. 79-103. 
Guest, D. (1987), "Human resource management and industrial relations", Journal of Management Studies, Vol. 24, No. 5, pp. 503-521.

Guest, D. (2004) "Flexible employment contracts, the psychological contract and employee outcomes: an analysis and review of the evidence", International Journal of Management Reviews, Vol. 5/6, No. 1, pp. 1-20.

Handy, C. (1989), The Age of Unreason, Business Books Limited, London.

Hendry, C. and Jenkins, R. (1997), "Psychological contracts and new deals", Human Resource Management Journal, Vol. 7, No. 1, pp. 38-44.

Herriot, P. and Pemberton, C. (1996), "Contracting careers", Human Relations, Vol. 49, No. 6, pp. $757-790$.

Herriot, P. and Pemberton, C. (1997), "Facilitating new deal”, Human Resource Management Journal, Vol. 7, No. 1, pp. 45-56.

Homans, G.C. (1961), Social Behavior: Its Elementary Forms, Harcourt Brace Jovanovich, New York.

Kernan, M.C. and Hanges, P.J. (2002), "Survivor Reactions to Reorganization: Antecedents and Consequences of Procedural, Interpersonal, and Informational Justice", Journal of Applied Psychology, Vol. 87, No. 5, pp. 916-28.

Kets De Vries, M.F.R. and Balazs, K., (1997), "The Downside of Downsizing”, Human Resources, Vol. 50, No. 1, pp. 11-50. 
Iles, P., Mabey, C. and Robertson, I. (1990), "HRM practices and employee commitment: Possibilities, pitfalls and paradoxes", British Journal of Management, Vol. 1, No. 2, pp. 147-157.

Kickul, J., Lester, S.W. and Finkl, J. (2002), Promise breaking during radical organizational change: do justice interventions make a difference, Journal of Organizational Behaviour, Vol. 23, No. 4, pp. 469-488.

Lazarus, R.S.. and Folkman, S. (1984), Stress, appraisal and coping, Springer Publishing Company, New York.

Legge, K. (1995), Human Resource Management, Rhetorics and Realities, Macmillan, Basingstoke.

Leventhal, G.S. (1976), "Fairness in Social Relationships", in Thibaut, J.W., Spence, J.T. and Carson, R.C. (Eds.), Contemporary Topics in Social Psychology, General Learning Press, Morristown, NJ, pp. 211-239.

Marler, J., Barringer, M. and Milkovich, G. (2002) "Boundaryless and traditional contingent employees: worlds apart", Journal of Organizational Behaviour, Vol. 23, No. 4 , pp. $425-453$.

Mayne, L., Tregaskis, O. and Brewster, C. (1996), "A comparative analysis of the link between flexibility and HRM strategy", Employee Relations, Vol. 18, No. 1, 524. 
Miles, M.B. and Huberman, A.M. (1994), Qualitative Data Analysis, Sage, Thousand Oaks, CA.

Millward, L.J. and Brewerton, P.M. (1999), "Contractors and their Psychological Contracts”, British Journal of Management. Vol. 10, No. 3, pp. 253-274.

Millward, N., Bryson, A. and Forth, J. (2000), All change at work? British employment relations 1980-1998, as portrayed by the workplace industrial relations survey series, Routledge, London.

Morrison, E. and Robinson, S.L. (1997), "When employees feel betrayed:a model of how psychological contract violation develops", Academy of Management Review, Vol. 22, No. 1, pp. 226-256.

Mueller, W.S. (1992), "Flexible working and new technology", in Hartley, J.F. (Ed.), Employment Relations: The Psychology of Influence and Control at Work, Blackwell, Oxford.

Pate, J., Martin, G. and McGoldrick, J. (2003) "The impact of psychological contract violation on employee attitudes and behaviour", Employee Relations, Vol. 25, No. 6, pp. 557-573.

Penn, R. (1992), "Flexibility in Britain during the 1980s: recent empirical evidence", in Gilbert, N., Burrows, R. and Pollert, A. (Eds.) Fordism and Flexibility: Divisions and Change. Basingstoke: Macmillan. 
Pidgeon, N. (1996), "Grounded theory: theoretical background", in Richardson, J.T.E. (Ed.), Handbook of Qualitative Research Methods for Psychology and the Social Sciences, BPS Books, Leicester, pp. 75-85.

Pollert, A. (1988) The 'flexible firm': fixation or fact? Work, Employment and Society, Vol. 2, No. 3, pp. 281-316.

Purcell, K. (2000), "Changing boundaries in employment and organisations", in , Purcell, K. (Ed.), Changing Boundaries in Employment, Bristol Academic Press, Bristol, pp. 1-30.

Rousseau, D.M. (1995), Psychological Contracts in Organizations, Sage, London.

Saunders, M.N.K. and Thornhill, A. (2004), "Trust and mistrust in organisations: An exploration using an organisational justice framework", European Journal of Work and Organisational Psychology Vol. 13, No. 4, pp. 492-515.

Storey, J. (1992), Developments in the Management of Human Resources, Blackwell, Oxford.

Tekleab, A.G., Takeuchi, R. and Taylor, M.S. (2005), "Extending the chain of relationships among organizational justice, social exchange, and employee reactions: the role of contract violations", Academy of Management Journal Vol. 48, No. 1 , pp. 146-157.

Thibaut, J. and Walker, L. (1975), Procedural Justice, Lawrence Erlbaum Association, Hillsdale, NJ. 
Turnbull, P. and Wass, V. (1997), “Job insecurity and labour market lemons: the (mis)management of redundancy in steel making, coal mining and port transport", Journal of Management Studies, Vol. 34, No. 1, pp. 27-51.

Watson, G. (1994), "The flexible work force and patterns of working hours in the UK" Employment Gazette, July, 239-247.

\section{ENDNOTE}

[1] "Temporary Employees as a percentage of Total Employees" [online] [cited 1 July, 2005] Available (Eurostat) http://epp.eurostat.cec.eu.int/portal/page?_pageid=1996,45323734\&_dad=portal\&_ schema=PORTAL\&screen=welcomeref\&open=/labour/EMPLOY/Employme/empte mp\&language=en\&product=EU_MASTER_labour_market\&root=EU_MASTER_labo ur_market\&scrollto=206http://europa.eu.int/comm/eurostat/newcronos/ 
Table I: Respondents contracts, preference for temporary and permanent work and psychological contract focus

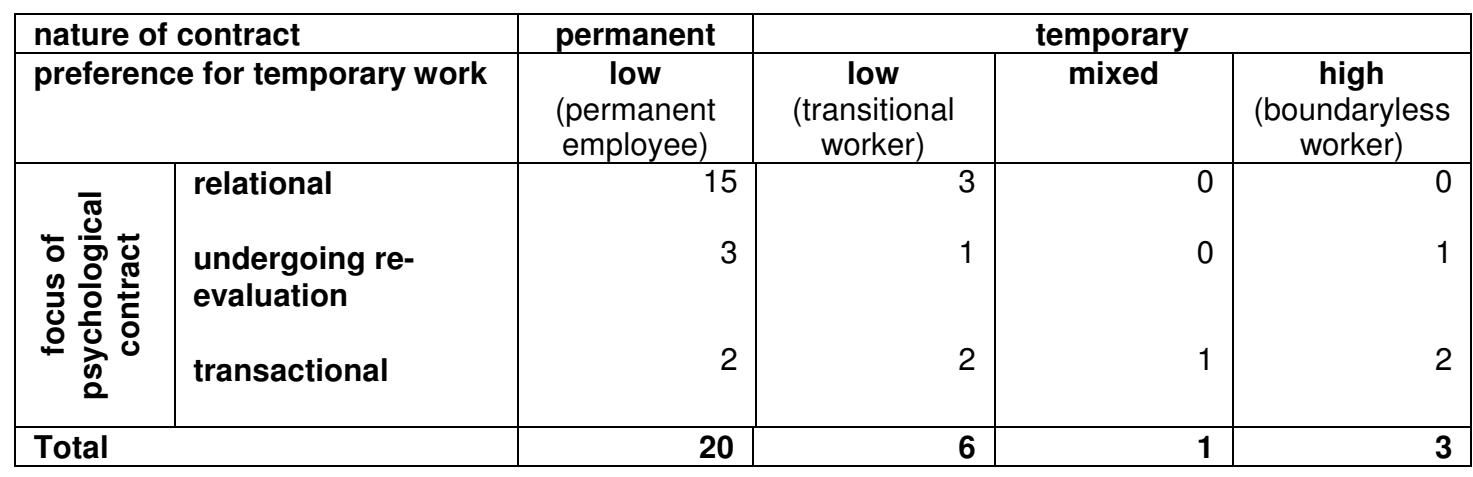


Table II: Respondents selecting each emotion as one of the three about which they felt most strongly

\begin{tabular}{|c|c|c|c|c|c|}
\hline \multirow{2}{*}{\multicolumn{2}{|c|}{$\begin{array}{l}\text { nature of contract } \\
\text { preference for } \\
\text { temporary work }\end{array}$}} & \multirow{2}{*}{$\begin{array}{c}\text { permanent } \\
\text { low } \\
\text { (permanent } \\
\text { employee) } \\
\end{array}$} & \multicolumn{3}{|c|}{ temporary } \\
\hline & & & $\begin{array}{c}\text { low } \\
\text { (transitional } \\
\text { worker) }\end{array}$ & mixed & $\begin{array}{c}\text { high } \\
\text { (boundaryless } \\
\text { worker) }\end{array}$ \\
\hline \multirow{3}{*}{ 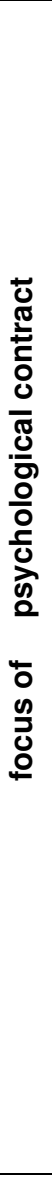 } & relational & $\begin{array}{l}\text { determined (11) } \\
\text { confident (6) } \\
\text { enthusiastic (4) } \\
\text { optimistic (4) } \\
\text { hopeful (3) } \\
\text { positive (3) } \\
\text { excited (2) } \\
\text { in control (2) } \\
\text { under pressure } \\
\text { (2) } \\
\text { cheerful } \\
\text { comfortable } \\
\text { confused } \\
\text { demoralised } \\
\text { expectant } \\
\text { involved } \\
\text { powerful } \\
\text { relieved }\end{array}$ & $\begin{array}{l}\text { keen (2) } \\
\text { determined } \\
\text { enthusiastic } \\
\text { hopeful } \\
\text { optimistic } \\
\text { positive } \\
\text { vulnerable } \\
\text { worried }\end{array}$ & & \\
\hline & $\begin{array}{l}\text { undergoing } \\
\text { re-evaluation }\end{array}$ & $\begin{array}{l}\text { confused } \\
\text { concerned } \\
\text { enthusiastic } \\
\text { frustrated } \\
\text { optimistic } \\
\text { resigned } \\
\text { mistrustful } \\
\text { resentful } \\
\text { vulnerable }\end{array}$ & $\begin{array}{l}\text { eager } \\
\text { frustrated } \\
\text { powerless }\end{array}$ & & $\begin{array}{l}\text { keen } \\
\text { optimistic } \\
\text { positive }\end{array}$ \\
\hline & transactional & $\begin{array}{l}\text { cheerful } \\
\text { demoralised } \\
\text { disinterested } \\
\text { enthusiastic } \\
\text { indifferent } \\
\text { positive }\end{array}$ & $\begin{array}{l}\text { insecure (2) } \\
\text { determined } \\
\text { hopeful } \\
\text { positive } \\
\text { vulnerable }\end{array}$ & $\begin{array}{l}\text { concerned } \\
\text { determined } \\
\text { positive }\end{array}$ & $\begin{array}{l}\text { calm } \\
\text { cheerful } \\
\text { comfortable } \\
\text { confident } \\
\text { positive } \\
\text { resigned }\end{array}$ \\
\hline & $\begin{array}{l}\text { Total } \\
\text { emotions }\end{array}$ & 60 & 18 & 3 & 9 \\
\hline
\end{tabular}

Note:

The 40 emotions from which respondents selected the three felt most strongly are: angry, calm, cheerful, comfortable, concerned, confident, confused, demoralised, depressed, determined, disinterested, eager, enthusiastic, excited, expectant, frustrated, hopeful, hopeless, in control, indifferent, insecure, involved, keen, mistrustful, on edge, optimistic, overwhelmed, panicky, positive, powerless, relaxed, relieved, resentful, resigned, secure, stressed, trusting, under pressure, vulnerable, worried. Those in italics were not selected by any respondents as one of their most strongly felt three and are not included in this table. 